\title{
Comparative analysis of common full scale reactors for dry anaerobic digestion process
}

\author{
Khaled Elsharkawy, Mohamed Elsamadony ${ }^{1}$, and Hafez Afify \\ Public Works Engineering Department, Faculty of Engineering, Tanta University, 31521 Tanta City, Egypt
}

\begin{abstract}
Organic solid wastes are produced with large amount wherever there are human activities. However, improper treated organic wastes made them as sources of diseases. On the other hand, these fractions contain nutrients and energy, so they have also valuable resources. As a result, exploring their potential as an energy source can be accomplish via anaerobic digestion process, in which, organics converted into hydrogen, methane and/or ethanol. Therefore, this manuscript introduces an overview of the common applied types of reactor that can handle these types of wastes in their solid state and recover them in term of biogas, as well as, stabilize the produced digestate to bio-fertilizers by compositing approach. A comparison also listed to demonstrate the optimum operational conditions and expected amount of biogas from each type.
\end{abstract}

\section{Introduction}

Incredible growing amount of solid waste is a crucial challenge worldwide. Consequently, environmental management of solid waste produced every year has to be safely disposed without any negative impact to the environment [1]. Anaerobic conversion of organic wastes to renewable source of energy appears to be one of the most promising methods [2, 3], since anaerobic digestion process can handle many types of organic solid waste such as organic faction of municipal solid waste (OFMSW) [4-6], industrial solid waste [7, 8] and agro-lignocellulosic waste [9-11]. These types of wastes are free of charge since they are waste and has to be disposed, plentiful, and composed of high organic fraction, which is preferable substrate to anaerobic consortium [12].

It must be noted that there are other technologies that have the ability to convert the organic wastes to energy form, i.e water electrolysis [13], as well as, thermo-catalytic reformation that can extract $\mathrm{H}_{2}$ gas from organic molecules [14]. The main drawback face this technologies is the electricity requisite during operation which limited the net gain energy and reduce the efficiency of these process. As a result, biological treatment of organic waste gains great interest especially anaerobic digestion process (AD). This is because being anaerobic which means no aeration tools are required, in turn, operational and maintenance costs are significantly reduced, besides AD has the ability to extract all the carbon and hydrogen atoms from organic molecule and transfer them to the form of methane $\left(\mathrm{CH}_{4}\right)$ and carbon dioxide $\left(\mathrm{CO}_{2}\right)$, in addition using mixed culture bacteria at the process make $\mathrm{AD}$ able to deal with different types of organic wastes $[15,16]$

$\mathrm{AD}$ process has been categorized into dry $\mathrm{AD}$ process that deal with waste contains total solid (TS) content larger than $20 \%(\mathrm{w} / \mathrm{w})$ and wet AD which only loaded with TS lower than $10 \%(\mathrm{w} / \mathrm{w})$. In this concern, dry AD found to be more efficient that wet type, since wet process requires large reactor capacity to handle the same amount of organic content due to the high water content. This surely will needs high energy for pumping, mixing and handling these amount of wet wastes. Furthermore, the produced digestate is larger than the dry process. Moreover, the net biogas production of dry will outweighs the wet production [17]. However, many different types of dry AD reactors were previously introduced, therefore an objective function must be applied to determine the optimum type to utilize for certain substrate [18]. Therefore, the aim of this manuscript is to describe the commercial types of dry $\mathrm{AD}$ reactors and compare between them in terms of operational conditions, advantages of each type and the estimated biogas production related to reactor capacity.

\footnotetext{
${ }^{1}$ Corresponding author: mohamed.elsamadony@f-eng.tanta.edu.eg
} 


\section{Anaerobic digestion pathway}

Organic compounds utilized anaerobically through a variety of microorganisms that cooperated in order to generate a stable anaerobic digestion process [11]. AD process starts with hydrolytic bacteria that hydrolyze polymeric proteins and sugars into monomeric molecules. Afterwards, fermentative bacteria create organic acids, hydrogen and carbon dioxide from monomeric molecules as declared in Fig. 1. Hence, hydrogen and acetic acid can be utilized and/or produced by several microbial groups. Acetate formed during homoacetogenesis process from hydrogen and carbon dioxide reduction by autotrophic homoacetogens through the Wood-Ljungdahl pathway [19].

Completion of organic particulates consumption by anaerobic consortia occurred when organic acids and $\mathrm{H}_{2}$ utilized by acetoclastic / hydrogenotrophic methanogens and generated methane and carbon dioxide [20].

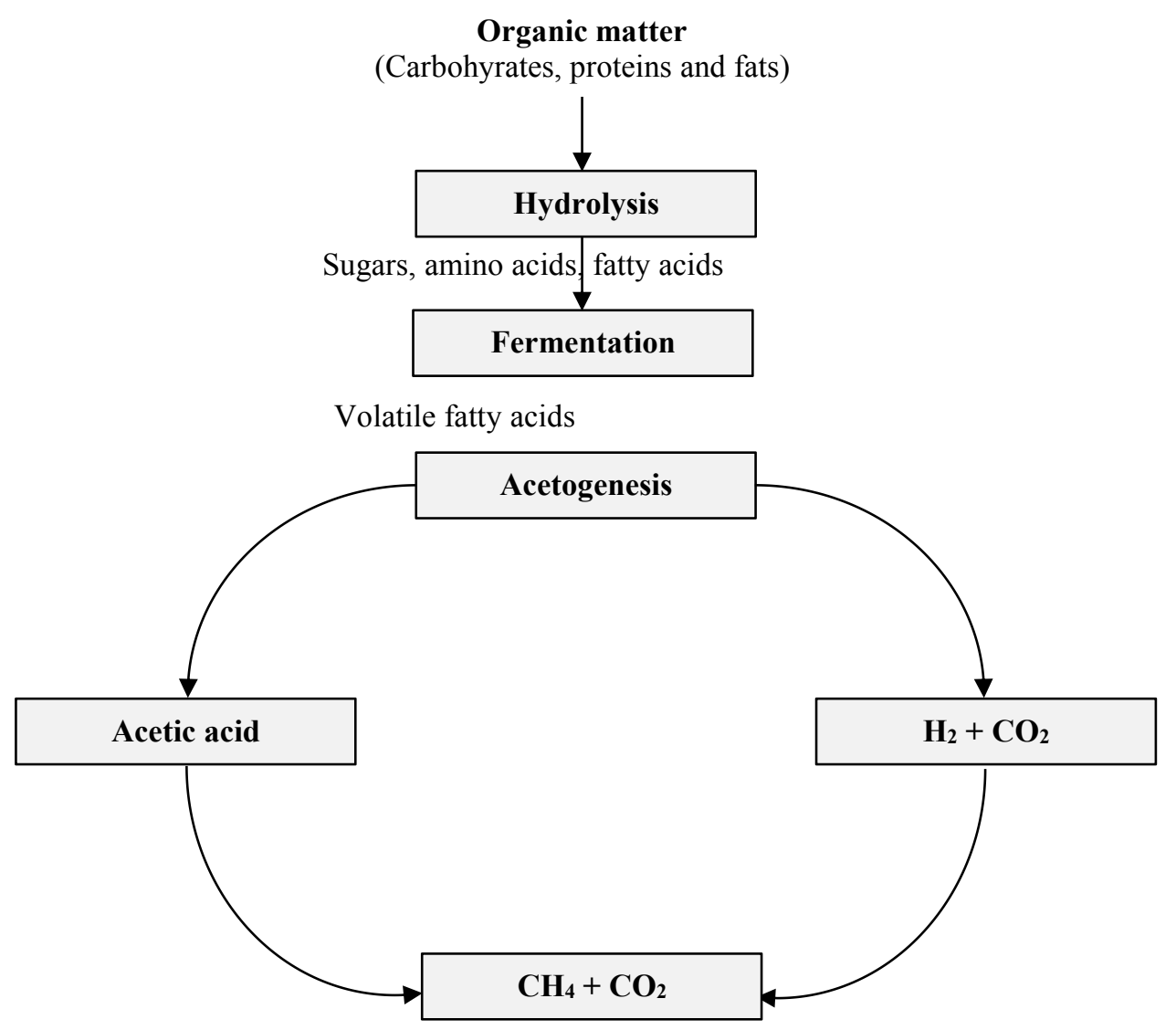

Fig. 1. Anaerobic degradation pathways of organic wastes.

\section{One stage commercial dry anaerobic systems}

Dry anaerobic system refers to systems that able to anaerobically treat organic waste with solid content in the range of $20-40 \%$. These systems require a good mechanically pretreatment tool to sustain smaller particle size and robust pumps to handle impurities [21]. Table 1 illustrates a comparison between the most common three designs of Kompogas, Valorga and Dranco process.

\section{Table 1}

Comparison between one stage commercial dry anaerobic digesters [22].

\begin{tabular}{|l|l|l|l|}
\hline $\begin{array}{l}\text { Reactor } \\
\text { type }\end{array}$ & KOMPOGAS & VALORGA & DRANCO \\
\hline $\begin{array}{l}\text { Country of } \\
\text { incorporation }\end{array}$ & Switzerland & France & Belgium \\
\hline Establish & 1980 & 1982 & 1992 \\
\hline
\end{tabular}




\begin{tabular}{|c|c|c|c|}
\hline year & & & \\
\hline No. of Plants & 38 & 22 & 17 \\
\hline $\begin{array}{l}\text { Capacity } \\
\text { (ton/year) }\end{array}$ & $1000-110000$ & $10000-270000$ & $3000-120000$ \\
\hline Advantages & $\begin{array}{l}\text { Can deal with organics } \\
\text { have solid content } \\
\text { doesn't exceed } 30 \% \\
\text { Full waste } \\
\text { stabilization and } \\
\text { hygienisation. } \\
\text { - } \begin{array}{l}\text { Stable biogas } \\
\text { production. }\end{array} \\
\text { Digestate free of } \\
\text { pathogens due to } \\
\text { thermophilic } \\
\text { conditions. } \\
\text { Avoiding short } \\
\text { circuiting of organic } \\
\text { waste. }\end{array}$ & $\begin{array}{l}\text { - This technique does not } \\
\text { require a large land } \\
\text { area. } \\
\text { - Baffles sustain a good } \\
\text { contact and avoid dead } \\
\text { zones. } \\
\text { - High net gain energy } \\
\text { with high methane } \\
\text { content gas. }\end{array}$ & $\begin{array}{l}\text { - Tolerate high solid } \\
\text { wastes to the range of } \\
30-45 \% \text { and high } \\
\text { organic loading rates of } \\
5-8 \mathrm{~kg} v / \mathrm{m}^{3} / \text { day. } \\
\text { - Small reactor volumes. } \\
\text { - Vertical reactor avoiding } \\
\text { waste accumulation. } \\
\text { - Minimum surface area } \\
\text { required for reactor } \\
\text { installation. } \\
\text { - Easy to operate with no } \\
\text { mixing or gas injection. } \\
\text { - Thermophilic operation } \\
\text { which avoid pathogens } \\
\text { formation. }\end{array}$ \\
\hline $\begin{array}{l}\text { Biogas Yield } \\
\left(\mathrm{m}^{3} / \mathrm{kg}\right)\end{array}$ & $0.08-0.16$ & 0.103 & $0.11-0.14$ \\
\hline $\begin{array}{l}\text { Retention } \\
\text { Time (Days) }\end{array}$ & $18-23$ & $15-30$ & 20 \\
\hline
\end{tabular}

Organic wastes in solid state have large scale which can't pass into the dranco system until they subjected to mechanical pretreatment to sustain a maximum particle size of $6 \mathrm{~cm}$. On the other hand, anaerobic digestion process is remarkably diminished when TS exceeds $35 \%$, therefore, dissolution using acidification process is required prior to introduce AD process. However, this step is unnecessary at Dranco system, since a digestate recirculation is applied with ratio $1 / 8$ of raw organic waste / effluent digested waste in order to confirm proper inoculation (Fig. 2). Moreover, the dranco system runs under thermophilic condition $\left(48\right.$ to $\left.55^{\circ} \mathrm{C}\right)$ via steam injection coupled with down flow mode as the mixture loaded to top of the digester using mixing recirculation pump. The designed operational conditions are hydraulic retention time (HRT), organic loading rate (OLR) and $\mathrm{pH}$ of 20 days, 5 to $8 \mathrm{~kg}$ vs $/ \mathrm{m}^{3} /$ day and 8 , respectively, as well as, this type can tolerate organic waste with TS content at the range of 30 to $45 \%$ (w/w). Furthermore, no supplemented stirrer attached to this type of reactor which attributed to localized dead zones inside the reactor body, in turn, the performance may be affected since the amount of generated biogas reduced by around 30\%. However, this design was applied at many countries with different capacities. The expected biogas yield is in the range of 110 to $140 \mathrm{~m}^{3} /$ ton and digestate amounted to be 0.4 ton/ton which further subjected to dewatering process and stabilized in composting bond. The net generated electricity after subtracting the utilized energy for operating the plant is approximately $150 \mathrm{kWh} /$ ton [23].

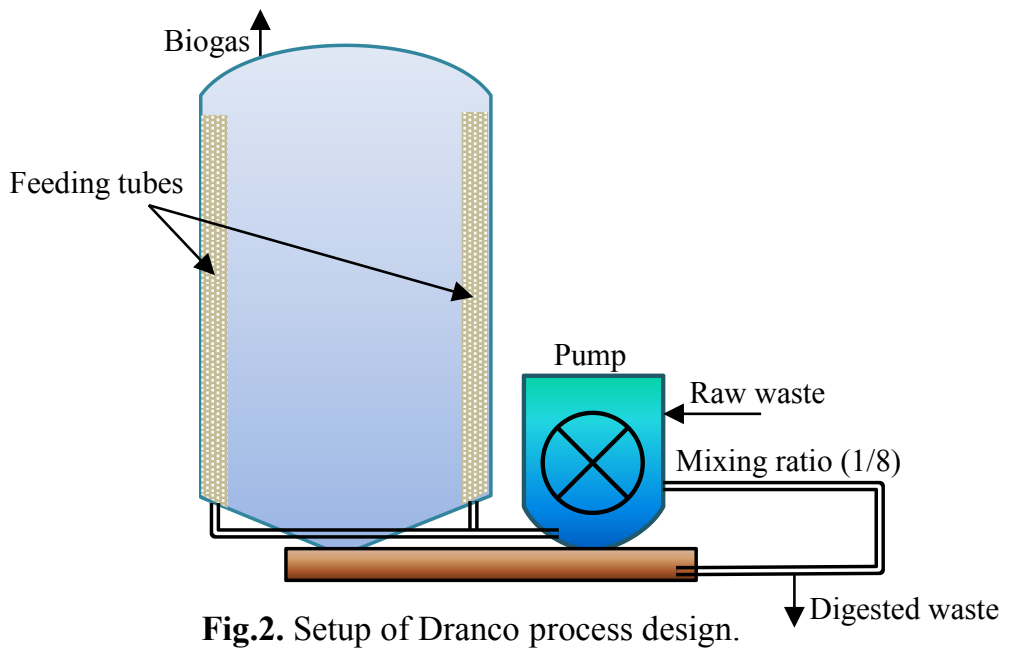


Kompogas reactor is similar to dranco design but with horizontal plug flow and inner slow rotators to provide homogeneous flow and avoid settling of heavier particles (Fig. 3). But the main disadvantage of this proposed design is take large surface area than dranco with same capacity. In addition, solid content lower than $23 \%$ and/or higher than $30 \%(\mathrm{w} / \mathrm{w})$ is a problematic issue, since at TS of $23 \%$ heavy particle sink and accumulate at the bottom of the reactor while exceeding $30 \%$ block the horizontal flow and hinder the process. As a result, a careful control of the influent TS at the limit of $30 \%(\mathrm{w} / \mathrm{w})$ is necessary. However, this design provides homogeneous flow avoiding short circuiting of organic waste. Moreover, the reactor runs at thermophilic condition $55-60{ }^{\circ} \mathrm{C}$ which guarantees killing pathogens at the effluent. The operational HRT ranged from 18 to 23 days and the harvested biogas is $80-160 \mathrm{~m}^{3} /$ ton [22].

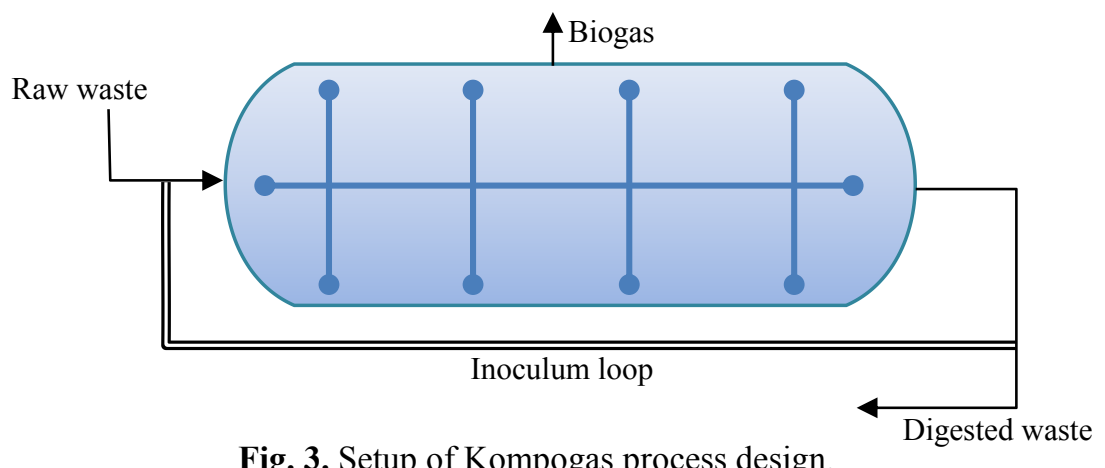

Valorga process (Fig. 4) started after the feedstock subjected to mechanical pretreatment to reduce the particle size to around $3 \mathrm{~cm}$ and mixed with returned effluent digestate and steam to provide mixture with temperature and solid content of $40{ }^{\circ} \mathrm{C}$ and $35 \%(\mathrm{w} / \mathrm{w})$ before $\mathrm{AD}$ process. The operational condition for Valorga system are HRT ranged from 15 to 30 days and $\mathrm{pH}$ around 8 without external use of chemicals. In the case of $\mathrm{pH}$ decline, the reactor operates at batch mode until $\mathrm{pH}$ recovered then continuous feeding regime start again. The stirring process occurs by biogas reinjection to the reactor with high pressure of 5 bar at the bottom of the reactor [24, 25]

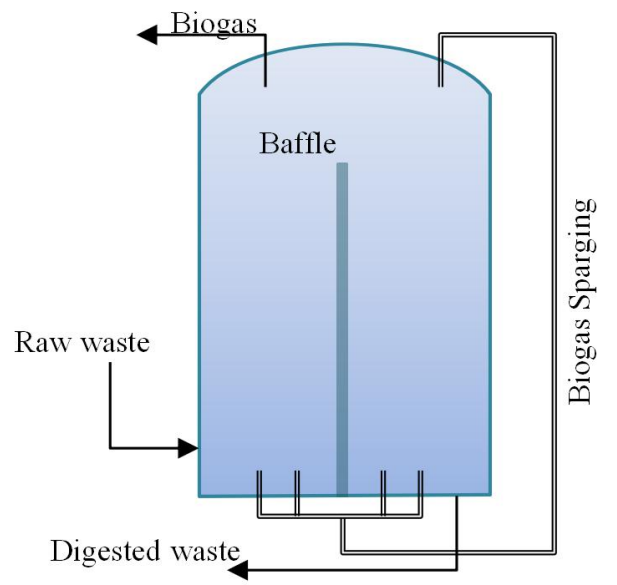

Fig. 4. Setup of Valorga process design.

Data collected from real installed reactors of each type have been displayed in Fig. 5 [22, 23], which presented the relation between the annual biogas productions versus the capacity of the reactor. Kompogas and Dranco process exhibited polynomial functions with correlation factors $\left(\mathrm{R}^{2}\right)$ of 0.94 and 0.99 , respectively. On the other hand, Valorga process showed power relationship with $\mathrm{R}^{2}$ of 0.94 . Moreover, each system was suitable to certain loading capacity, whereas, Kompogas was better than other types when dealing with capacity lower than 50000 t/year. This was not the case when capacity exceeding this limit, in which, Dranco was the best at the medium loading capacity less than 100000 t/year, however, large capacity over the aforementioned limit exihibited a reduction in the performance of Kompogas and Dranco, while Valorga revealed maximum biogas generation. 


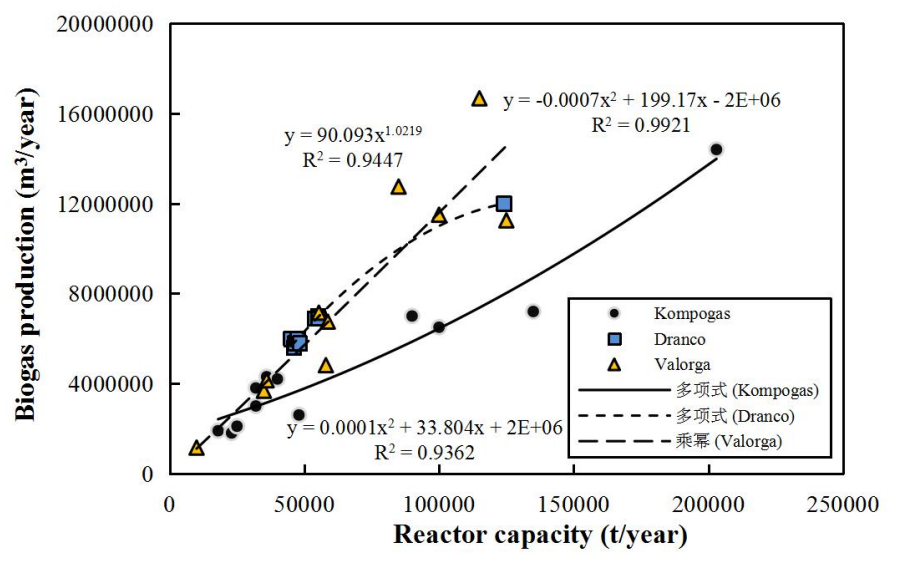

Fig. 5. Comparative production harvested from real full scale digesters

\section{Conclusions}

Dry anaerobic digestion is a pioneer strategy that able to disposal of organic solid wastes by converting them into biogas generation and fertilizer. There are three main types of reactor Kompogas, Dranco and Valorga, each one has its advantage and disadvantage. However, from energetic point of view, collected data exhibited that Kompogas is recommended at low reactor capacity lower than 50000 t/year, while Dranco is preferable at medium reactor capacity below 100000 t/year. However, Valorga found to have a superior performance in term of annual biogas generation at high reactor capacity exceeded 100000 t/year.

\section{References}

1. Elsamadony, M., Tawfik, A., Danial, A., Suzuki, M.: Use of Carica Papaya Enzymes for Enhancement of H2 Production and Degradation of Glucose, Protein, and Lipids. Energy Procedia. 75, 975-980 (2015).

2. Ismail, S., Elsamadony, M., Elreedy, A., Fujii, M., Tawfik, A.: Physico-chemical and microbial characterization of compartment-wise profiles in an anammox baffled reactor. J. Environ. Manage. 232, 875-886 (2019).

3. Ismail, S., Elsamadony, M., Fujii, M., Tawfik, A.: Evaluation and optimization of anammox baffled reactor (AnBR) by artificial neural network modeling and economic analysis. Bioresour. Technol. 271, 500-506 (2019).

4. Elsamadony, M., Tawfik, A., Danial, A., Suzuki, M.: Optimization of hydrogen production from organic fraction of municipal solid waste ( OFMSW ) dry anaerobic digestion with analysis of microbial community. Int. J. Energy Res. 39, 929-940 (2015).

5. Elsamadony, M., Tawfik, A.: Dry anaerobic co-digestion of organic fraction of municipal waste with paperboard mill sludge and gelatin solid waste for enhancement of hydrogen production. Bioresour. Technol. 191, 157-165 (2015).

6. Elsamadony, M., Tawfik, A., Suzuki, M.: Surfactant-enhanced biohydrogen production from organic fraction of municipal solid waste (OFMSW) via dry anaerobic digestion. Appl. Energy. 149, 272-282 (2015).

7. Farghaly, A., Elsamadony, M., Ookawara, S., Tawfik, A.: Bioethanol production from paperboard mill sludge using acid-catalyzed bio-derived choline acetate ionic liquid pretreatment followed by fermentation process. Energy Convers. Manag. 145, 255-264 (2017).

8. Mostafa, A., Elsamadony, M., El-Dissouky, A., Elhusseiny, A., Tawfik, A.: Biological $\mathrm{H} 2$ potential harvested from complex gelatinaceous wastewater via attached versus suspended growth culture anaerobes. Bioresour. Technol. 231, 9-18 (2017).

9. Soltan, M., Elsamadony, M., Tawfik, A.: Biological hydrogen promotion via integrated fermentation of complex agro-industrial wastes. Appl. Energy. 185, 929-938 (2017).

10. Elsamadony, M., Tawfik, A.: Maximization of hydrogen fermentative process from delignified water hyacinth using sodium chlorite. Energy Convers. Manag. 157, 257-265 (2018).

11. Wazeri, A., Elsamadony, M., Tawfik, A.: Carbon emissions reduction by catalyzing H2 gas harvested from water hyacinth fermentation process using metallic salts. Energy Procedia. 152, 
1254-1259 (2018).

12. Dias, T., Fragoso, R., Duarte, E.: Anaerobic co-digestion of dairy cattle manure and pear waste. Bioresour. Technol. 164, 420-3 (2014).

13. Turner, J., Sverdrup, G., Mann, M.K., Maness, P., Kroposki, B., Ghirardi, M., Evans, R.J., Blake, D.: Renewable hydrogen production. Int. J. Energy Res. 32, 379-407 (2008).

14. Irmak, S., Öztürk, İ.: Hydrogen rich gas production by thermocatalytic decomposition of kenaf biomass. Int. J. Hydrogen Energy. 35, 5312-5317 (2010).

15. Tawfik, A., Salem, A.H.: Optimization of hydrogen production from pretreated rice straw waste in a mesophilic up- fl ow anaerobic staged reactor. Int. J. Energy Res. (2013).

16. Wazeri, A., Elsamadony, M., Roux, S. Le, Peu, P., Tawfik, A.: Potentials of using mixed culture bacteria incorporated with sodium bicarbonate for hydrogen production from water hyacinth. Bioresour. Technol. 263, 365-374 (2018).

17. Romero Aguilar, M. a., Fdez-Güelfo, L. a., Álvarez-Gallego, C.J., Romero García, L.I.: Effect of HRT on hydrogen production and organic matter solubilization in acidogenic anaerobic digestion of OFMSW. Chem. Eng. J. 219, 443-449 (2013).

18. Elsheikh, M.A., Saleh, H.I., Rashwan, I.M., El-Samadoni, M.M.: Hydraulic modelling of water supply distribution for improving its quantity and quality. Sustain. Environ. Resour. 23, 403411 (2013).

19. Mu, V.: Energy Conservation in Acetogenic. Appl. Environ. Microbiol. 69, 6345-6353 (2003).

20. Tawfik, A., Elsamadony, M.: Development of Dry Anaerobic Technologies of Bio-waste and Unlock the Barriers for Valorization. In: Purohit, H.J., Kalia, V.C., Vaidya, A.N., and Khardenavis, A.A. (eds.) Optimization and Applicability of Bioprocesses. pp. 267-282. Springer Singapore, Singapore (2017).

21. Elsamadony, M., Tawfik, A.: Potential of biohydrogen production from organic fraction of municipal solid waste (OFMSW) using pilot-scale dry anaerobic reactor. Bioresour. Technol. 196, 9-16 (2015).

22. Rapport, J., Zhang, R., Jenkins, B.M., Williams, R.B., Schwarzenegger, A., Adams, L.S., Brown, M.R., Chair, B., Chesbro, W., Member, B., Petersen, G., Mulé, R.: Current Anaerobic Digestion Technologies Used for Treatment of Municipal Organic Solid Waste. (2008).

23. De Baere, L.: The Dranco Technology: A unique digestion technology for solid organic waste. Org. Waste Syst. Pub. Brussels, Beligium. 1-8 (2010).

24. Benbelkacem, H., Bollon, J., Bayard, R., Escudié, R., Buffière, P.: Towards optimization of the total solid content in high-solid (dry) municipal solid waste digestion. Chem. Eng. J. 273, 261267 (2015).

25. Benbelkacem, H., Garcia-Bernet, D., Bollon, J., Loisel, D., Bayard, R., Steyer, J.P., Gourdon, R., Buffière, P., Escudié, R.: Liquid mixing and solid segregation in high-solid anaerobic digesters. Bioresour. Technol. 147, 387-394 (2013). 